\title{
The Analysis to Minimize the Loss of Fuel during National Road Maintenance Project in Bali, Indonesia
}

\author{
Dewa Ketut Sudarsana \\ Civil Engineering Department, Udayana University, Bali, Indonesia \\ dksudarsana@unud.ac.id
}

\begin{abstract}
Work zone on the execution of road maintenance projects always has negative impacts such as reduced traffic performance. The excesses of the decline in traffic performance are loss of fuel consumption of in motor vehicles. Studies minimize loss of fuel during the execution of a road improvement project in Indonesia needs to be done. Case study is the execution of National road improvement of two-lane two-way, urban and interurban road type in the Bali Provincial of fiscal year 2015. Analysis of the traffic performance using the Indonesian Highway Capacity Manual 1997. Analysis of fuel consumption using guidelines Pd.T-15-2005-B. Loss of fuel of the daytime, hourly time relationship was analysed with statistical methods. The average of loss of fuel for seven link roads obtained is 176 litres day per $\mathrm{km}$. Model curves obtained is the polynomial three of the degree. Work hours of execution of road maintenance projects that pose minimal loss of fuel is at night working time between 11 PM to 6 AM.
\end{abstract}

Keyword - Road maintenance, Loss of fuel, Minimize, Working.

\section{INTRODUCTION}

Road infrastructure in order to serve the road users' condition for always steady. In order to maintain steady maintenance condition. The type of road maintenance handling depends on the level of road damage. The phenomenon during the execution of road maintenance is always a negative impact for road users and the surrounding environment. This impact occurs as part of the road lane road is used in the work zone. This working zone is used as a work space during road maintenance execution [1], [13]. This work zone resulted in traffic disruption such as delayed travel, congestion and also accidents [2]-[5], [17].

Research on the negative impacts of work zones during the execution of road projects generally takes into road user cost [1], [6]. The loss of road users consists of losses due to increased vehicle operating costs (VOC) and increased time value losses. The dominant component of VOC of the dominant road users is due to the increase of fuel oil consumption [2], [4], [5], [7]. In the implementation of a two-lane two lane National Road Reconstruction maintenance project in Bali province in 2013, it was found that the loss of fuel energy reached 145 litres /day/link road [5]. This paper specifically discusses the effort to minimize loss of fuel energy consumption during the execution of the National road maintenance project in Bali province of Indonesia.

\section{MATERIALS AND METHODS}

The execution of road maintenance, especially the improvement of two lane, two-way National Road in the province of Bali in the 2015 fiscal year is used as a case study. Descriptive methods are used to describe traffic characteristics and traffic regulation patterns during road maintenance execution [8], [14]. Stages of discussion of the research are presented in the form of diagrams in Figure 1. 


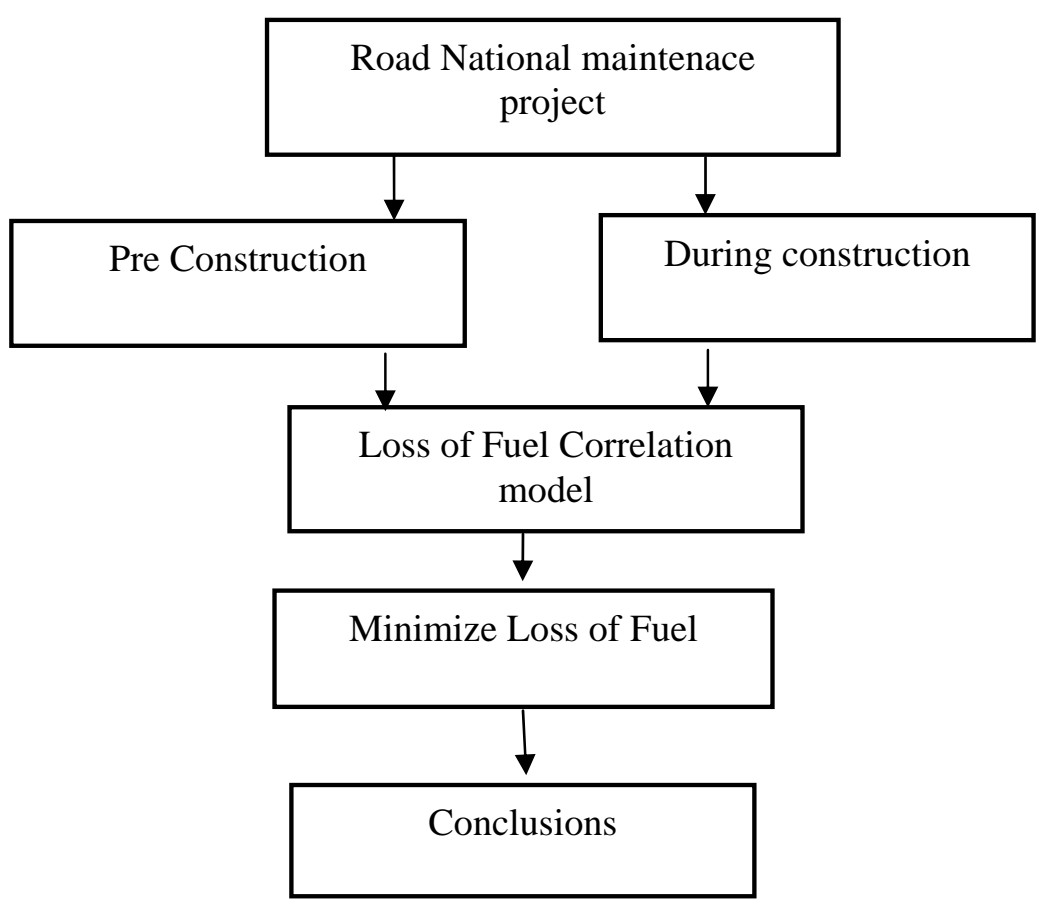

Figure 1. Framework Diagram of Research

Research stages such as Figure 1 can be explained:

\section{A. Data Collection}

The premier data collection is performed by direct project location. Secondary data are compiled from government and secret offices. Primary data types consist of [15], [16]:

1) Survey of traffic regulation patterns in work zone.

2) Survey of road geometric dimension

3) Survey environment around work zone location.

4) Survey of traffic volume and vehicle speed. This survey uses automated traffic counting equipment (Automatic Traffic Counting = ATC). The type of equipment used is the trademark Golden River (GR) type Marksman 400 (M400) or abbreviated GR M400.

\section{B. Analysis of Fuel Energy Consumption}

Performance of traffic of pre-construction condition and during the construction period using the method of the Highway Capacity Manual of Indonesia 1997. The measured traffic performance variable is the average speed of the vehicle $(\mathrm{V})$, traffic volume $(\mathrm{Q})$, road capacity $(\mathrm{C})$, degree of saturation (DS) and travel time (T) (DJBM, 1997). This traffic performance variable is analysed in 2 conditions, namely pre-construction condition and during construction. These variables are then used to calculate the loss of fuel during the road maintenance project execution. In the guideline (Pd-T-2005-B) formulated fuel consumption formulation for various types of vehicles, can be seen in equation (1) [9].

The fuel consumption (FC) for each vehicle can be calculated by equation (1) [5].

$$
\begin{aligned}
\mathrm{FC}= & \left(\alpha+\beta_{1} / \mathrm{V}_{\mathrm{R}}+\beta_{2} \times \mathrm{V}_{\mathrm{R}}^{2}+\beta_{3} \times \mathrm{R}_{\mathrm{R}}+\beta_{4} \times \mathrm{F}_{\mathrm{R}}+\beta_{5} \times \mathrm{F}_{\mathrm{R}}^{2}+\beta_{6} \times \mathrm{DT}_{\mathrm{R}}\right. \\
& \left.+\beta_{7} \times \mathrm{A}_{\mathrm{R}}+\beta_{8} \times \mathrm{SA}+\beta_{9} \times \mathrm{BK}+\beta_{10} \times \mathrm{BK} \times \mathrm{A}_{\mathrm{R}}+\beta_{11} \times \mathrm{BK} \times \mathrm{SA}\right) / 1000
\end{aligned}
$$

Where:

$$
\begin{array}{ll}
\mathrm{FC} & =\text { Fuel Consumption } \\
\alpha & =\text { Constant } \\
\beta_{1} \ldots \beta_{11} & =\text { Parameter coefficients } \\
\mathrm{V}_{\mathrm{R}} & =\text { Average of speed } \\
\mathrm{R}_{\mathrm{R}} & =\text { Average of road ramp up } \\
\mathrm{F}_{\mathrm{R}} & =\text { Average sloop down the road } \\
\mathrm{DT}_{\mathrm{R}} & =\text { Degree of average curve road }
\end{array}
$$


$\mathrm{A}_{\mathrm{R}} \quad=$ Average of acceleration

SA $=$ Standard deviation of speed

\section{Analysis o Loss of Fuel ( $\mathrm{LoF})$}

Variations of traffic performance in pre-construction and construction conditions, if substituted in equation (1), then derived formulation of loss of fuel (LoF) as in equation (2) [10],

$$
\begin{aligned}
\mathrm{LoF}= & \left\{\beta_{1}(1-\mathrm{Fv}) /(\mathrm{Vp} \cdot \mathrm{Fv})+\beta_{2} \cdot \mathrm{Fv}^{2}(\mathrm{Vp}-1)^{2}+0.128\left(\beta_{7}+\beta_{10} . \mathrm{BK}\right) \times(\mathrm{Fds}-1)\right. \\
& \left.+0.78\left(\beta_{8}+\beta_{11} \times \mathrm{BK}\right) \cdot\left(1 /\left(1+\mathrm{e}^{(-3.1540)^{\star} \mathrm{Fds} \mathrm{FSp}^{*}}\right)-1 /\left(1+\mathrm{e}^{(-3.1540)^{*} \mathrm{DSp}}\right)\right)\right\} / 1000
\end{aligned}
$$

Volume adjustment factor parameters (Fq), vehicle speed (Fv), and degree of saturation (Fds) are parameters used to adjust traffic performance from preconstruction conditions to during construction. The magnitude of this parameter is $\mathrm{Fq}=0.91, \mathrm{Fv}=0.90$ and $\mathrm{Fds}=1.23$ [10].

The result of analysis of loss of fuel (LoF) obtained, then determined curve trend with statistic method (Bhattacharyya, 1977). The curves obtained are optimized by finding the minimum values mathematically [12].

\section{RESULTS AND DISCUSSIONS}

Package of road improvement / reconstruction in fiscal year 2015 under Bali BPJN authority found as many as 8 road packages. The name of the package / link road is presented in Table I.

TABLE 1. List of road links as a case study

\begin{tabular}{cllc}
\hline No & Cases & \multicolumn{1}{c}{ Package Name/ link road } & Length $\mathbf{( k m )}$ \\
\hline 1 & B1 & Cekik-Seririt & 4,00 \\
2 & B2 & Cekik-Batas Kota Negara & 1,80 \\
3 & B3 & Batas Kota Amlapura-Angentelu & 2,30 \\
4 & B4 & Jalan Sutomo, Stiabudi, Wahidin, Thamrin, & 6,78 \\
5 & B5 & Simpang Kuta-Banjar Taman & 1,70 \\
6 & B6 & Simpang Pesanggaran-Sesetan & 5,32 \\
7 & B7 & Cekik-Batas Kota Singaraja & 3,80 \\
\hline
\end{tabular}

Notation of variable traffic performance for pre-construction and during construction/execution conditions can be seen in Table II.

TABLE II. Notation of traffic variables in pre-construction condition $(\mathrm{P})$ and execution time (E).

\begin{tabular}{llllllll}
\hline No & Case & \multicolumn{2}{l}{ Speed, V(km/hour } & \multicolumn{2}{l}{ Volume, Q (pcu) } & \multicolumn{2}{l}{ Degree of Saturated, DS } \\
\cline { 3 - 7 } & & $\mathbf{P}$ & $\mathbf{E}$ & $\mathbf{P}$ & $\mathbf{E}$ & $\mathbf{P}$ & $\mathbf{E}$ \\
\hline 1 & B1 & V1p & V1e & Q1p & Q1e & DS1p & DS1e \\
2 & B2 & V2p & V2e & Q2p & Q2e & DS2p & DS2e \\
3 & B3 & V2p & V2e & Q2p & Q1e & DS2p & DS2e \\
4 & B4 & V4p & V4e & Q4p & Q4e & DS4p & DS4e \\
5 & B5 & V5p & V5e & Q5p & Q5e & DS5p & DS5e \\
6 & B6 & V6p & V6e & Q6p & Q6e & DS6p & DS6e \\
7 & B7 & V7p & V7e & Q7p & Q7e & DS7p & DS7e \\
\hline
\end{tabular}

Pre-construction traffic performance (notation p) from a survey and compilation results in traffic volume (Qp) can be seen in Figure 2, Figure 3 for vehicle speed (Vp) and Figure 4 for saturation degree (DSp). While during the execution traffic performance (notation e) which includes Qe, Ve and DSe is calculated from the preconstruction traffic performance multiplied by the adjustment factor i.e. Fq for volume, Fv for speed and Fds for the degree of saturation. 


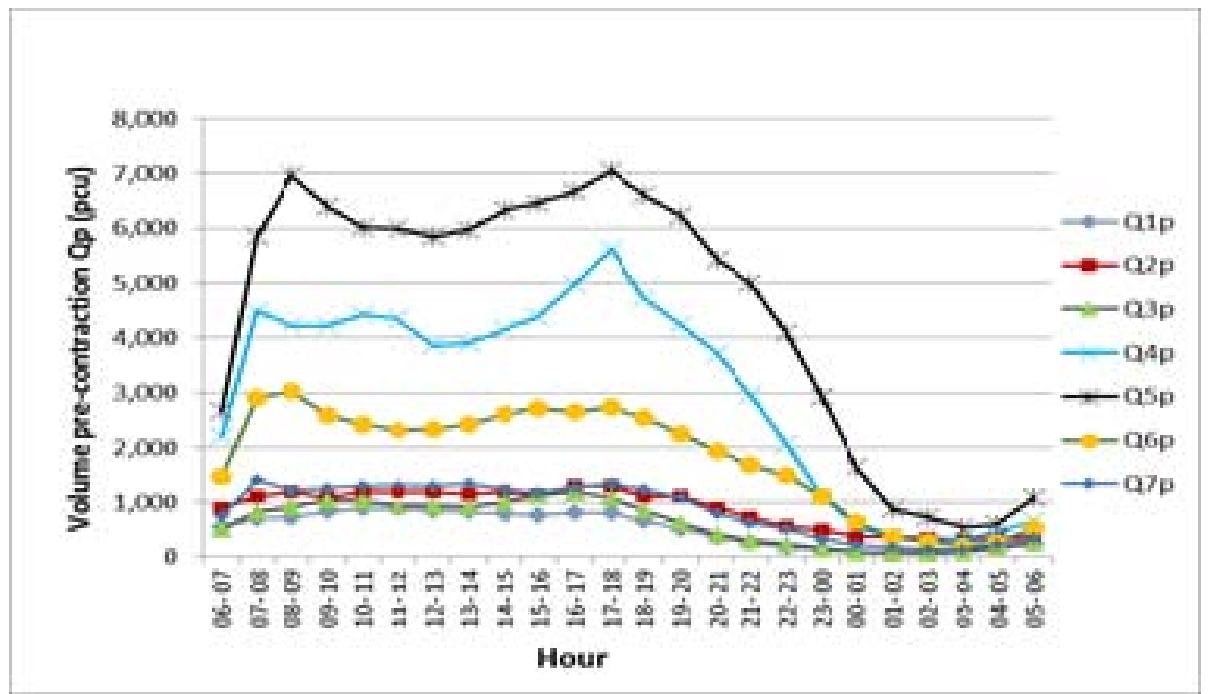

Figure 2. Fluctuations Volume of pre-construction vehicle Qp (pcu)

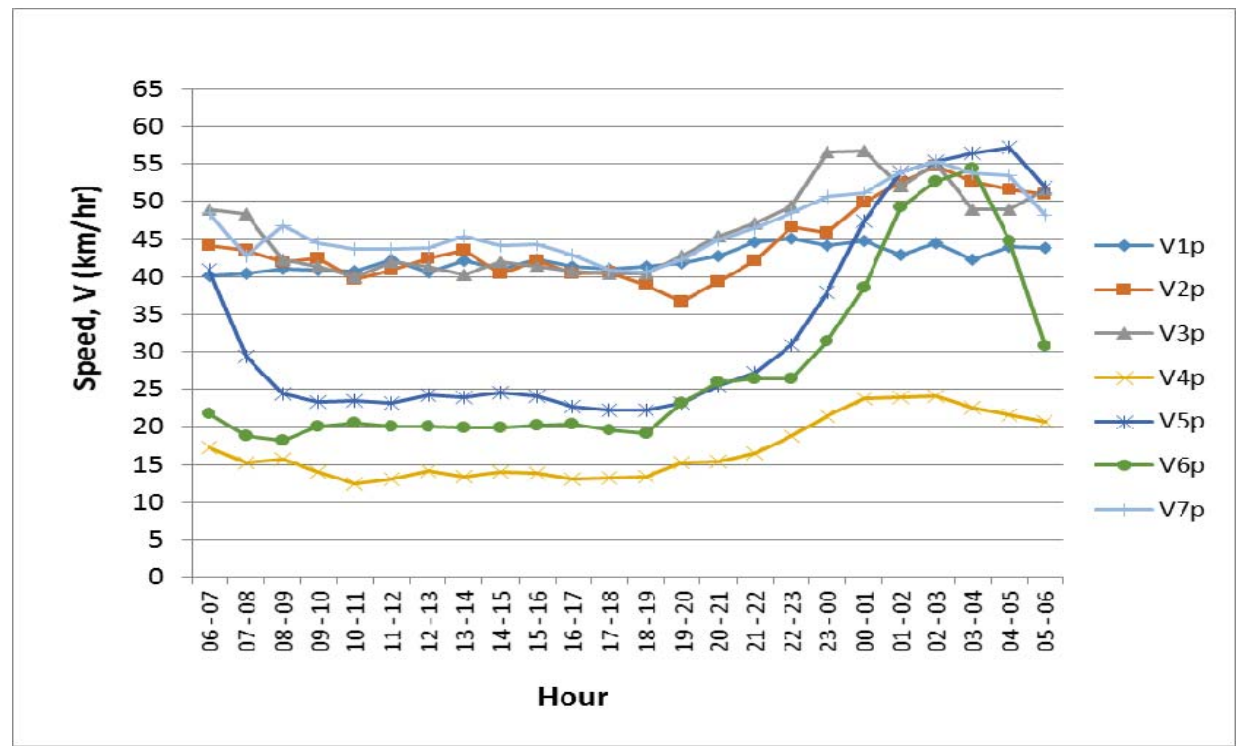

Figure 3. Vp vehicle speed fluctuations (km / hr)

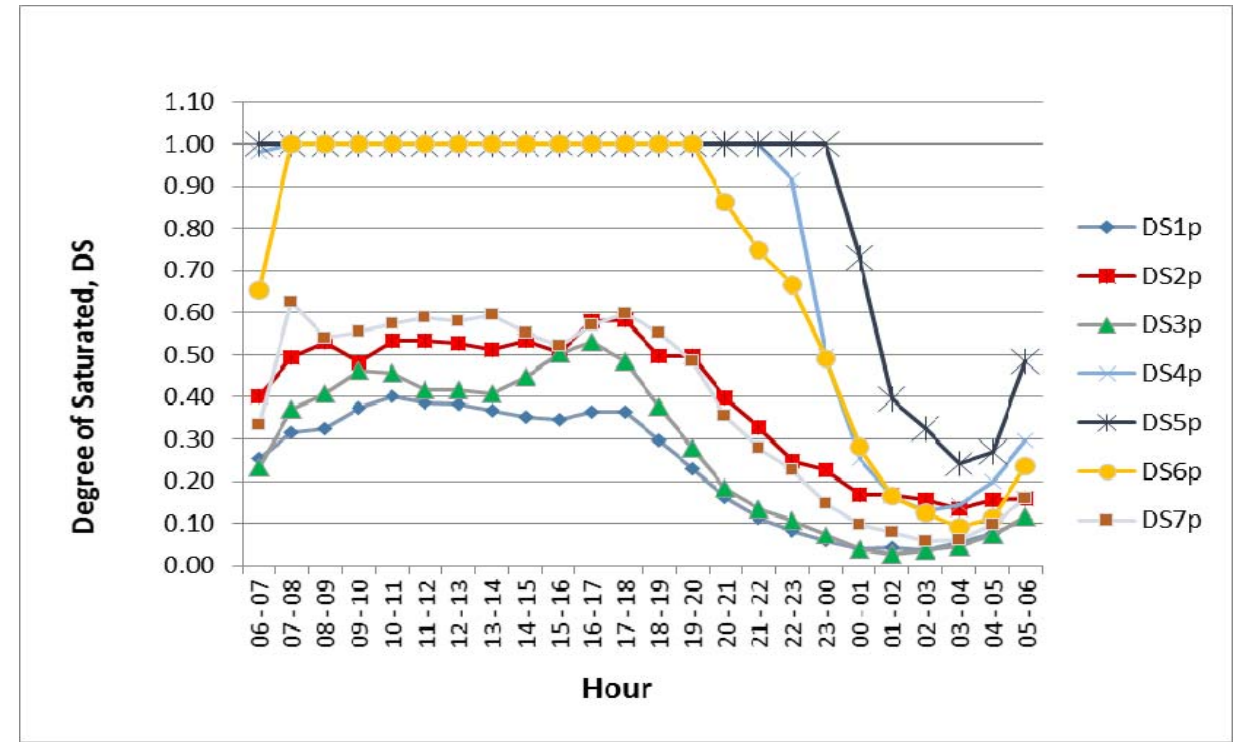

Figure 4. The degree of saturation DSp fluctuation 


\section{A. Loss of Energy Fuel Analysis.}

The loss of fuel of energy can be calculated using the formula (2). By entering the traffic performance variable in the precondition, during execution and related parameters of running cost analysis refer to Pd-152005-B, it is obtained loss of fuel LoF of each link road B1, B2, B3, B4, B5, B6 and B7 presented in Table III.

TABLE III. Loss of fuel (LoF) in the case study

\begin{tabular}{cccccccccc}
\hline \multirow{2}{*}{ Hour } & & \multicolumn{7}{c}{ LoF (liter)/Link road } \\
& Hourly & B1 & B2 & B3 & B4 & B5 & B6 & B7 & Average \\
\hline $06-07$ & 1 & 1.7 & 3.0 & 1.6 & 4.9 & 1.5 & 3.9 & 3.1 & 2.7 \\
$07-08$ & 2 & 3.5 & 6.6 & 4.6 & 16.3 & 7.9 & 13.2 & 9.1 & 8.7 \\
$08-09$ & 3 & 4.7 & 8.4 & 6.7 & 20.7 & 13.3 & 17.9 & 9.0 & 11.6 \\
$09-10$ & 4 & 5.5 & 7.1 & 7.2 & 27.4 & 16.6 & 19.3 & 8.9 & 13.2 \\
$10-11$ & 5 & 7.1 & 9.1 & 8.2 & 38.7 & 20.6 & 23.7 & 10.3 & 16.9 \\
$11-12$ & 6 & 6.1 & 8.8 & 7.1 & 40.2 & 22.6 & 26.2 & 10.3 & 17.4 \\
$12-13$ & 7 & 6.0 & 8.8 & 7.1 & 28.2 & 16.4 & 20.1 & 10.4 & 13.9 \\
$13-14$ & 8 & 6.5 & 9.1 & 7.4 & 30.1 & 16.9 & 20.4 & 12.4 & 14.6 \\
$14-15$ & 9 & 5.9 & 9.0 & 8.1 & 20.5 & 11.8 & 14.5 & 10.5 & 11.5 \\
$15-16$ & 10 & 5.5 & 8.1 & 8.8 & 23.0 & 13.3 & 15.9 & 10.0 & 12.0 \\
$16-17$ & 11 & 6.0 & 9.7 & 9.1 & 16.9 & 9.8 & 11.0 & 10.7 & 10.4 \\
$17-18$ & 12 & 5.8 & 9.4 & 7.9 & 16.4 & 9.7 & 11.1 & 10.9 & 10.1 \\
$18-19$ & 13 & 3.0 & 4.7 & 3.9 & 17.4 & 10.7 & 12.4 & 6.9 & 8.3 \\
$19-20$ & 14 & 2.1 & 3.5 & 2.6 & 15.6 & 10.3 & 10.3 & 5.8 & 7.1 \\
$20-21$ & 15 & 1.4 & 3.1 & 1.7 & 18.7 & 11.4 & 11.2 & 3.5 & 7.3 \\
$21-22$ & 16 & 1.0 & 2.4 & 1.1 & 12.7 & 7.5 & 7.7 & 2.5 & 5.0 \\
$22-23$ & 17 & 0.7 & 2.0 & 0.8 & 4.0 & 2.3 & 2.8 & 1.9 & 2.1 \\
$23-00$ & 18 & 0.3 & 1.5 & 0.4 & 1.7 & 0.8 & 1.1 & 1.0 & 1.0 \\
$00-01$ & 19 & 0.2 & 0.9 & 0.2 & 0.9 & 0.2 & 0.4 & 0.5 & 0.5 \\
$01-02$ & 20 & 0.2 & 0.8 & 0.1 & 0.4 & 0.1 & 0.1 & 0.4 & 0.3 \\
$02-03$ & 21 & 0.1 & 0.7 & 0.2 & 0.5 & 0.0 & 0.1 & 0.3 & 0.3 \\
$03-04$ & 22 & 0.2 & 0.5 & 0.2 & 0.7 & 0.0 & 0.1 & 0.2 & 0.3 \\
$04-05$ & 23 & 0.4 & 0.6 & 0.3 & 0.4 & 0.0 & 0.1 & 0.5 & 0.3 \\
$05-06$ & 24 & 0.5 & 0.7 & 0.5 & 0.6 & 0.1 & 0.4 & 1.0 & 0.5 \\
Total per day & 74.3 & 118.5 & 95.6 & 356.8 & 203.9 & 244.1 & 140.1 & 176.0 \\
\hline
\end{tabular}

To see trends from the spread of the loss of fuel, then presented in the form of scatter diagrams, can be seen Figure 5.

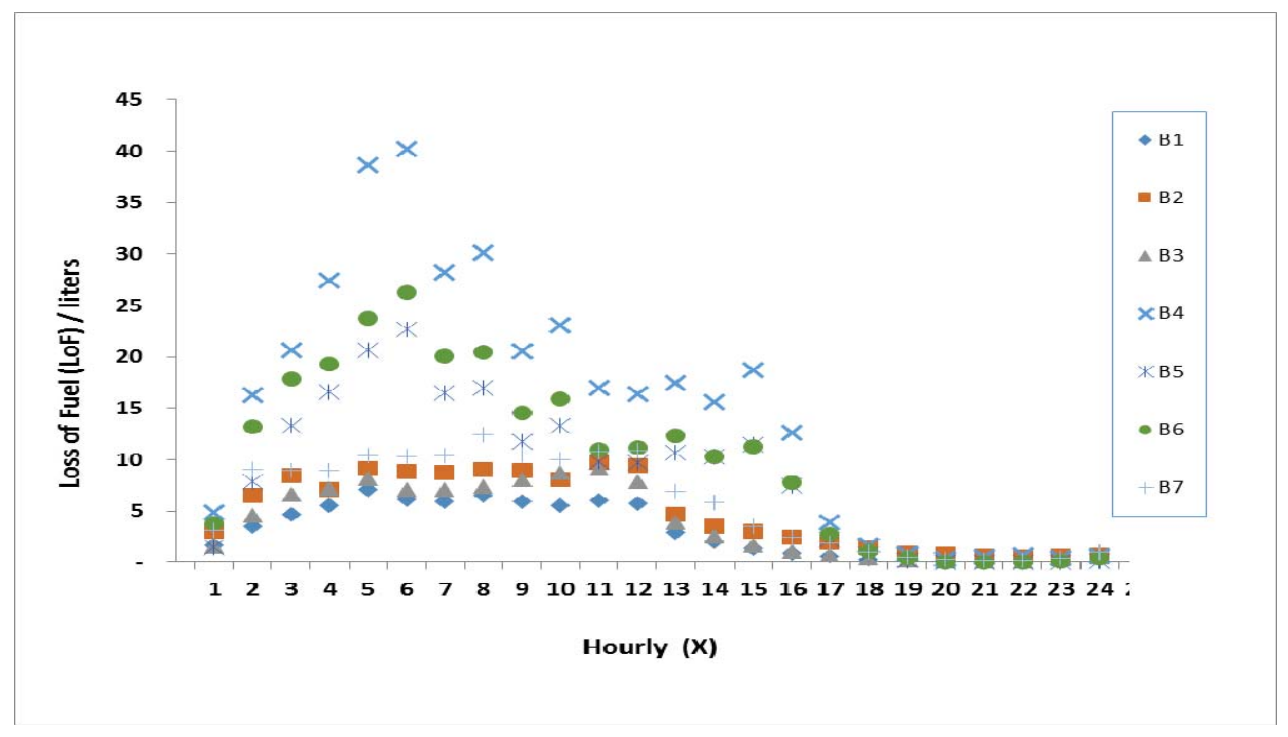

Figure 5. The scatter diagram of Loss of fuel (LoF) 
In Table III and Figure 5, it can be explained the fluctuation of a loss of fuel LoF in curfew tends to be less than during the daytime hours. This is due to the mobility of the community more during the day than at night. Daily loss of fuel LoF can be seen as the lowest in the case of the B1 (Cekik-Seririt link road), while the highest in B4 case (Setiabudi-Cokroaminoto link road). This is in line with urban road type B4 (SetiabudiCokroaminoto link road) and interurban B1 (Cekik-Seririt link road). The average loss of fuel during the construction period of road improvement is found as much as 176.0 litters/day/link road

\section{B. Relation of Loss of Fuel with Time (Hours)}

The relationship between loss of fuel (Love) with time $(\mathrm{T})$ has a fairly close relationship ( $\mathrm{r}=0.72$ ). Based on the closeness of this relationship, then the curve trend is determined by the relationship between the two variables Lof with $\mathrm{T}$. Variable $\mathrm{LoF}$ as a response variable, and the time variable (T) as a variable generator. The result of the analysis shows that the curve model of the relationship between LoF and $\mathrm{T}$ is a three-degree polynomial model. The equation of the obtained curve is formulated in equation (3), and can be seen in Figure 6 .

$\mathrm{Y}=0.0107 \mathrm{x} 3-0.4479 \mathrm{x} 2+4.641 \mathrm{x}+1.259$

Where:

$\mathrm{Y}=\mathrm{LoF}=$ Loss of fuel

$\mathrm{x}=\mathrm{T}=$ valid from 1 st to 24 th hour

The coefficient of determination, $\mathrm{R}^{2}$ obtained is $\mathrm{R}^{2}=0.521$, which can be stated that the relationship model is influenced by another factor of $47.9 \%$, besides the working time $(\mathrm{T})$.

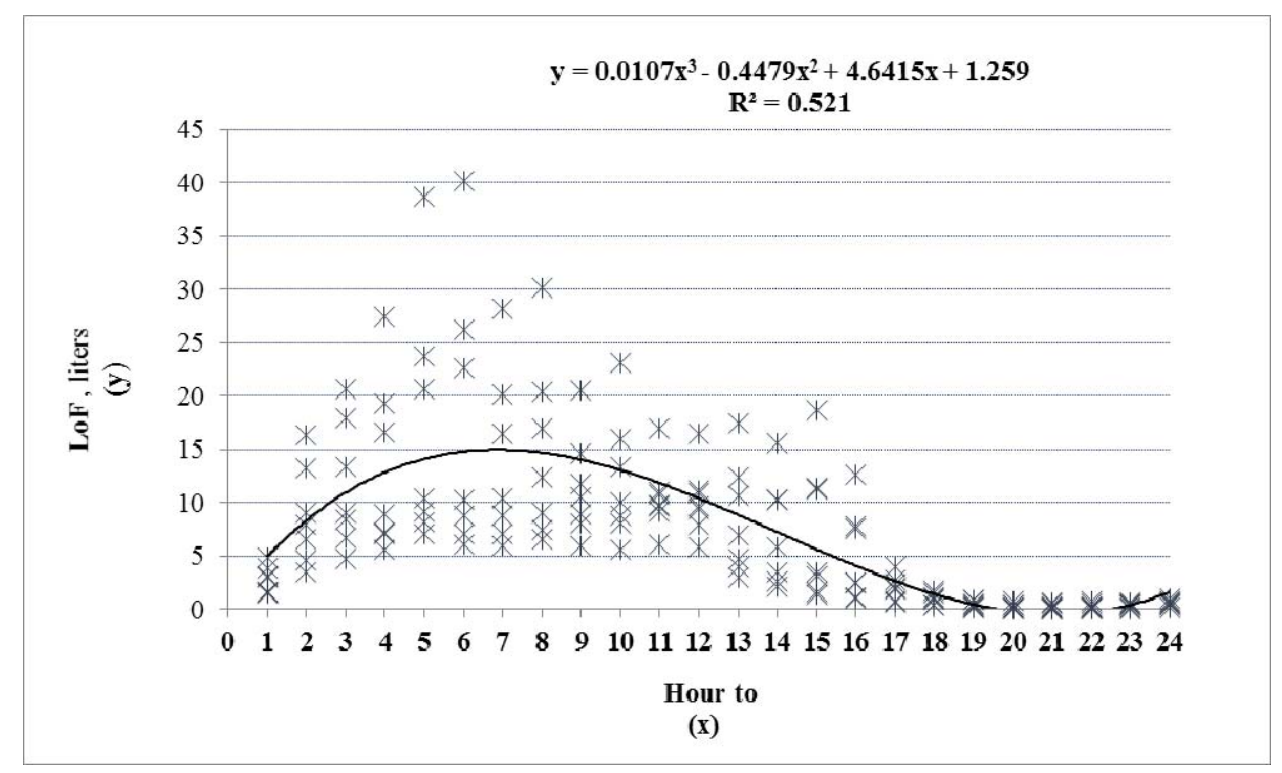

Figure 6. LoF (Y) and T (x) relationship model.

C. Minimizing Loss of Fuel (LoF) In Work Zones.

From the equation model (3) obtained, we can determine the minimum turning curve to determine minimum loss of fuel. The turning point of the bend can be determined by calculating the derived function:

$\mathrm{y}=0.0107 \mathrm{x} 3-0.4479 \mathrm{x} 2+4.6415 \mathrm{x}+1.259$

To determine the maximum and minimum points of the curve are:

$\mathrm{dy} / \mathrm{dx}=0$, then

$\mathrm{dy} / \mathrm{dx}=0.0321 \mathrm{x} 2-0.8958 \mathrm{x}+4.6415=0$

Then got it

$\mathrm{x} 1=21$ th hour, and $\mathrm{x} 2=7$ th hour.

This means that the maximum point of loss of fuel occurs at the 7th hour (12: 00-13: 00 PM) as much as 15.47 litres/ km, while the minimum occurs on the 21st hour (02: 00-03: 00 AM) of 0.29 litres. So the working time that affects the minimum loss of fuel is between 02:00 to 03:00 AM. If working at this 1 hour only, it is deemed ineffective and inefficient for resource allocation assignments i.e. employees, labours and equipment. To be more effective and efficient the assignment of resources requires the addition of working time. The approach taken is to determine the night working time that is from 18:00 PM (13rd hour) to 06:00 AM (24th hour). The variation of the night working time from the 13th hour to the 24th hour is determined by the standard deviation, s. By using statistic formulation, the value of $s$ is 3 hours. Furthermore, by applying the 21st hour, 
which leads to a minimum loss of fuel LoF, as the midpoint of the night work hour, the working hour interval that raises the minimum loss of fuel LoF is:

$$
\begin{aligned}
& x 1,2=x 21 \pm 3 \\
& x 1,2=21 \pm 3
\end{aligned}
$$

Then obtained:

$$
\mathrm{x} 1 \text { = 18th hour, and } \mathrm{x} 2 \text { = 24th hour }
$$

So it can be determined the range of night working time that leads to minimum and efficient LoF in human resource assignments and equipment's starting from 18:00 PM (18th hour) to 06:00 AM (24th hour), it can be seen in Figure 7.

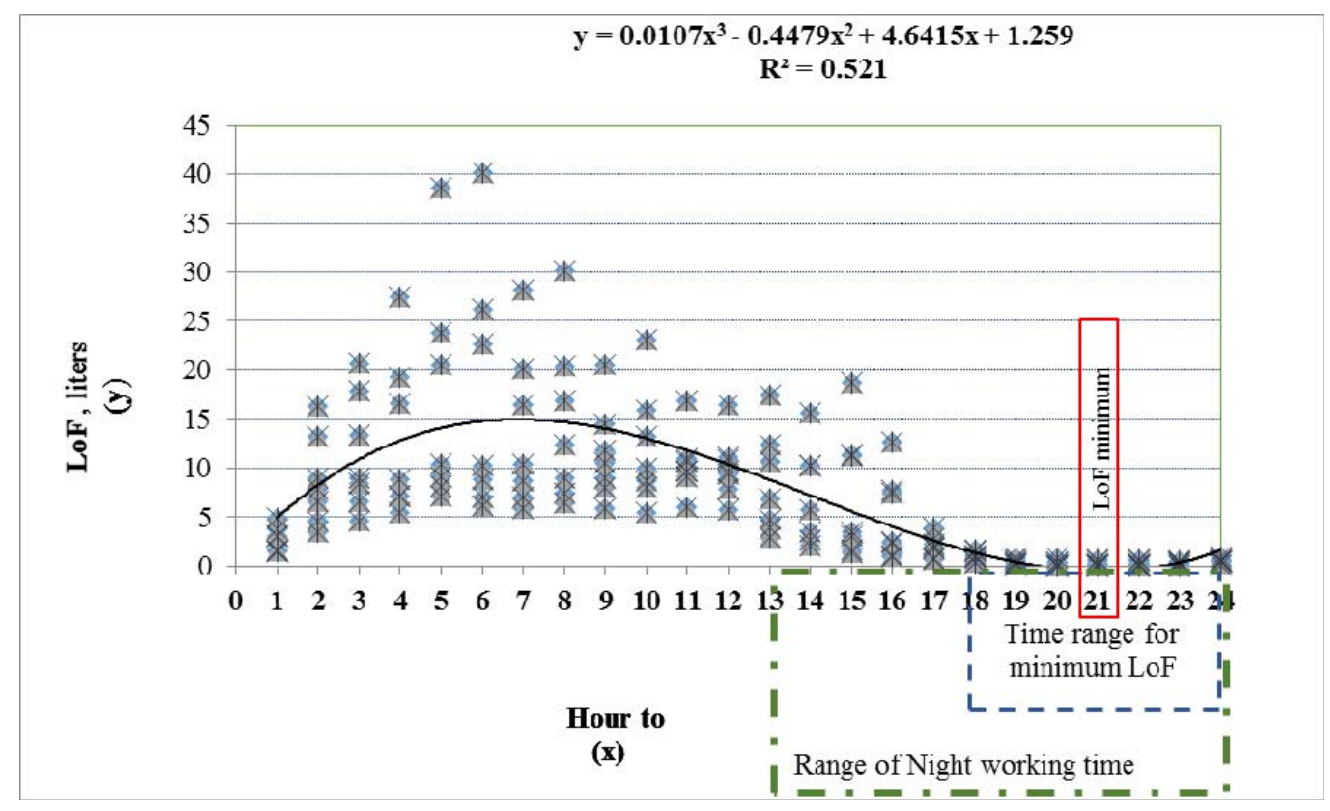

Figure 7. Time range minimum Loss of Fuel (LoF) in a day.

\section{CONCLUSION}

From the analysis result to minimize loss of fuel during National road maintenance, especially road improvement / reconstruction project for 2 lane 2 way, urban and inter-urban type in Bali province, it can be concluded that's the loss of fuel energy during the execution project average $176 \mathrm{lifter} / \mathrm{day} / \mathrm{km}$. Loss of fuel consumption found in working hours during the day is 12:00 AM to 13:00 AM, as many as 15.47 litres while the minimum is found to occur in 02:00-03: $00 \mathrm{AM}$ as much as 0.29 litres / km. Effective working hours of resources assignment and with minimum loss of fuel impact is from 23:00 PM to 06:00 AM.

\section{ACKNOWLEDGMENT}

Acknowledgments to all parties related to this research, especially Balai Pelaksana Jalan Nasional (BPJN) Bali and LPPM Udayana University who has funded the research.

\section{REFERENCES}

[1] Y. Jiang, H. Chen, Li., "Determination of Context and Incentive and Disincentive Value of Highway Construction Project" International Journal of Construction Education and Research., vol. 6.pp. 285-302, 2010

[2] D.K. Sudarsana, H. Sulistio, A. Wicaksono and L. Djakfar, "The Analysis Of Work Zone Road User Costs Due To The Delay Completion Of The Road Maintenance Project” Advances in Natural Application Sciences.,vol. 8 (3) pp: 103-108. 2014.

[3] D.K. Sudarsana , H. Sulistio, A. Wicaksono and L. Djakfar, "A Study of Safe and Green Infrastructure on Road Reconstruction Project”., Advances Environmental Biology., vol. 8(10), pp. 616-620, 2014

[4] D.K. Sudarsana , H. Sulistio, A. Wicaksono and L. Djakfar, The Analysis of Speed Degree Of Saturation Traffic Flow Model On The Road Reconstruction Project. Australian Journal of Basic \& Application Sciences., vol.8(9), pp. 207-212. 2014

[5] D.K. Sudarsana, H. Sulistio, A. Wicaksono and L. Djakfar, "Predict of loss of fuel during the road reconstruction in Indonesia”. Proc. Green Building, Materials and Civil Engineering, 2014.

[6] E.N. Allouche, A. Gilcrist, Quantifying Construction Realized Social Costs, North American Society for Trenchless Technology (NASTT), New Orleans, Lusiana, 2004

[7] D.K. Sudarsana, Participation Study Calculation of Time Values Factor in Contract of Road Construction Project (Case: Road Improvement and Bridge Replacement Project of Bali Province), Thesis, Graduate Program, Civil Engineering Study Program, Istitut Teknologi Sepuluh Nopember Surabaya,1998

[8] M. Nazir, Research Methods (Metode Penelitian). Ghalia Indonesia, Jakarta, 2003.

[9] DPU (Ministry of Public Works) Balitbang, SNI Pd.T-15-2005-B Vehicle Operation Cost Calculation for Running Cost (Perhitungan Biaya Oerasi Kendaraan untuk Biaya Tak Langsung). 2005.

[10] D.K Sudarsana D.K, Model of Road User Disadvantage during the Implementation Period of the Road Reconstruction Project. Dissertation, Doctoral Program of Civil Engineering, Faculty of Engineering, Universitas Brawijaya Malang, 2014. 
[11] G.K. Bhattacharyya, and R.A. Johnson, Statistical Concepts and Methods. John Wiley and Sons, 1977.

[12] K.A. Stroud, E. Sucipto, Engineering Mathematics, 3rd ed. Erlangga Jakarta, 1991

[13] K. Choi, Y.H. Kwak, B. Yu, "Quantitative Model for Determining Incentive / Disincentive Amounts through Schedule Simulation", Proc. of the 2010 Winter Simulation Conference, 2010.

[14] A. Ferdinan, Management Research Methods: Research Guidelines For Thesis Writing, Thesis and Dissertation Management Science (Pedoman Penelitian Untuk Penulisan Skripsi, Tesis dan Disertasi Ilmu Manajemen), 3rd ed. Diponogoro University Publisher Agency, Semarang,2011.

[15] D.J.B.M (Directorate General of Highways) \& Sweroad, Indonesia Highway Capacity Manual (Manual Kapsitas Jalan di IndonesiaMKJI), Jakarta, 1997.

[16] D.J.B.M (Directorate General of Highways), Road Safety Practical Instructions at Working Zone on the Road (Petunjuk Praktis Keselamatan Jalan Pada Zona Kerja Di Jalan), Jakarta, 2010

[17] J.C. Matthews, E.N. Allouche, A Social Cost Calculator for Utility Construction Project, Proc. Paper F-4-03, NASTT-No-Dog Show, 2010. 